UDC 339.138

JEL Classification: M31

http://doi.org/10.21272/mmi.2018.4-25

\author{
Afzal Hossain, \\ Comilla University, Bangladesh \\ Md Yusuf Hossein Khan, \\ University of Algarve, Portugal, \\ International University of Business Agriculture and Technology, Bangladesh
}

\title{
GREEN MARKETING MIX EFFECT ON CONSUMERS BUYING DECISIONS IN BANGLADESH
}

Abstract. Green is a widely-used term that can mean a wide variety of things to different people. Green marketing is a modern philosophy that can be applied to end user goods, manufacturing goods and even services. Green marketing is the marketing of products that are acknowledged to be ecologically safe. Green marketing integrates a wide range of activities, comprising product modification, production method changes, packaging change, price change as well as modifying the promotional theme. This paper aims to explore the green marketing mix effect on consumers' buying decisions in Bangladesh. This investigation adopts the quantitative analysis of green marketing mix that may influence consumers' buying decisions. By using Convenient and Judgmental Sampling Technique, the data has been collected from 200 respondents. Data are analysed using frequency, mean, standard deviation and regression analysis. From the results of regression analysis, this research is revealed that green product and green promotional activities as the important elements, which influence consumers buying decisions. This paper has implications for marketers as well as green consumers and makes a good case for introduce of an era of greening in Bangladesh. This study shows that consumers' buying decisions really seem influenced by marketing mixes like the green product and green promotional activities. So, marketers should maintain promotional campaigns for increasing the knowledge regarding greening. Marketers also have to develop more displays, samples, commercialization and distribution in order to green information available. This paper can assist greening development along with determining the consumers buying decisions. This exploration provides realistic direction and pertinent suggestions to the greening firms. Greening firms will be profited identifying green marketing mix elements of consumers buying decisions. Those categories of the greening practising firms will offer to Bangladeshi consumers for buying decisions. As a result, consumption patterns will be inevitably enhanced and created demand for forthcoming consumers in Bangladesh.

Keywords: Bangladesh, buying decisions, consumers, green marketing, green marketing mix.

Introduction. Green marketing which is mentioned as ecological marketing too is a procedure that is applied nowadays even in emerging nations. Due to the matter of conserving the green consumers' reexamination regarding the green products they buy. At the present time, most of the consumers are willing to pay a premium price for the green products which observe ecological morals for real protection of the surroundings (Kotler \& Armstrong, 1999). Green marketing has to be maintained production of green products without waste instead of getting rid of waste, environmental commitment by re-inventing the concept of eco-friendly product, the price of the green products portraying the real cost, create profit by creating the operational occasions that derive from the environmental conscience in the market (Pride \& Ferrel, 2008). Green marketing as planned by marketing researchers comprises ecological marketing and social marketing (Soonthonsmai, 2007). Green marketing is a communal procedure that consumers and assemblies fulfil their requirements through a moral technique which reduces the undesirable influences on the environment by means of replacing the green products and their importance (Dahl, U. \& Persson, 2008). Green marketing as the controlling procedure accountable for recognizing, forecasting and satisfying the necessities of consumers and society in a lucrative and ecological method (Peatitie, 1995; Welford, 2000). Consumers are more conscious about the societal and conservational issues the more consumers have participated in pro-social and pro-environmental actions (Panni, 2006). Green awareness

Cite as: Hossain, A., \& Khan, M. Y. H. (2018). Green Marketing Mix Effect on Consumers Buying Decisions in Bangladesh. Marketing and Management of Innovations, 4, 298306. http://doi.org/10.21272/mmi.2018.4-25 
is demarcated as identifying the influence of human actions on the environment. Ecological awareness has both an intellectual, knowledge-based element and a sentimental, perception-based element (Kollmuss \& Agyeman, 2002). Green products awareness has changed the role of consumers to reveal their accountability to save the world before buying activities (Cherian \& Jacob, 2012). Consumers have a tendency to evaluate the features of a definite green product sensibly and regard its impact on the environment (Gan et al., 2008; Prakash, 2002). Green product as the product that will not contaminate the world natural resources and can be reused or preserved (Shamdasami et al., 1993). It is a product that has more ecologically sound content in decreasing the conservational effect (Wasik, 1996). Consumers who are conscious of and fascinated by ecological concerns are called green consumers (Soonthonsmai, 2007). Consumers acknowledged green products when their key requirement for superiority, performance, accessibility and affordability were encountered, and when they understood how an environment-friendly product could aid to resolve green difficulties (Ottman, 1992). Bangladesh is an emerging and densely populated country in South Asia. In 2012, its population is about 160 million. Bangladeshi producers will find that green marketing is a tough concept. They may understand that green marketing in Bangladesh still at its fetus period. The government of Bangladesh has to inspire and aid producers who are producing green products by providing subsidies. Economical support should be given in the form of the easy loan facility to equip for producing green products.

This paper is allocated in the following segments. Firstly, the literature review is provided based on the past study. Secondly, objectives of the study. Thirdly, conceptual framework and research hypotheses. Fourthly, methodologies are explained which are applied to the study. Next part of the study is presented with the results and discussion. After that, the conclusions and implications are described for the interested parties like academicians, researchers, greening companies etc. Finally, the limitations and further investigation scope are represented.

Literature Review. Marketing Mix is the set of manageable variables that companies can practice impacting the purchaser's response (Kotler \& Armstrong, 2009). Green marketing 4P's are that of a conventional marketing but the challenge before marketers and manufacturers are to practice 4 P's in a creative manner. Statistical analysis exposed that green marketing mix elements and consumers purchase intention are positively related to each other (Mahmoud, 2018).

Green Product. An ecological brand is only capable to exist when it is exemplified honestly in products and practices one of significant marketing mix features is products (Martin \& Schouten, 2012). The green product is using renewable resources for the product (Sivesan, et al. 2013). Most of the consumers are conscious of green products. Consumers' green products consciousness is vital in guiding the buying decisions. The research discovered that green products as a significant factor, which extensively influences consumers buying decisions (Siddique \& Hossain, 2018). Producers need sturdy products to defend the product's content form purchaser abuse and physical damage, as well as the flexible outdoor design of the product to survive false lights and climatic excesses at all times. Environmental products have been anticipated to be less damaging to the atmosphere by dropping layers of wrapping, diminishing products size or alternating old substantial using biodegradable assets. However, also of understanding the benefits of lightly weighted wrapping, such as cutting-down engineering expenditure, promotional value and affirmative environmental impact; green products has acknowledged analyses and examination from consumers in terms of protect-function achievement (Kassaye \& Verma, 1992). An eco-friendly product may be defined as a product that is produced using environmentally-friendly measures and toxic-free ingredients which is licensed by are cognized companies (Kumar \& Ghodeswar, 2015).

Green Price. Environmental marketing would acquire all these facts into consideration though charging a high price (Bukhari, 2011). D'Souza et al. (2006) revealed that all of the products offered should be ecologically safe except an essential to pay premium prices for them. Green price mentions to the price indicated in the light of the company's strategies with regard to ecological thought imposed by rules and 
enterprise guidelines or its creativities in this concern (Hashem \& Al-Rifai, 2011). Green product price should be reasonable for the consumers which inspire them to buy green products (Yazdanifard \&Mercy, 2011). Consumers pay is really the cost of a green product is called the price. It is a significant component of the marketing mix. Most the consumers will only be ready to pay a high if there is an opinion on supplementary green product value (Kalama, 2007). The green price is the charge paid for a product. It is a significant component of the marketing mix. Most the consumers are the willingness to pay a high if there is a perception on supplementary product value (Eric, 2007). Green pricing is the toughest problems of environmental marketing. If ecological expenses and community are reflected in the offered price to the consumers who intend to pay such price, producers will be inspired to generate more sustainability. Companies which interest such costs and transfer them to the consumers are challenged with two dangers of being charged with wronging of consumers' intent as well as comparative enhancing of prices in comparison with the competitors (Durning, 2011).

Green Place/Distribution. Green distribution is a very subtle procedure. Customers must be assured of the environmental nature of the product (Yazdanifard \& Mercy, 2011). The delivery method is the consolidation associations between the company and consumers. In the environmental marketing delivery scheme as called as the green place is the dissemination gates that smoothing the distribution and to secure processes conducting within conservational circumstances and necessities (Hashem\& Al-Rifai, 2011). The green place is regarding handling logistics to reduce the delivery emissions, thereby in impact pointing at dropping the carbon footprint and in common ecological contamination (Shil, 2012). The place is not a cost producer issue, it has various elements that may create revenue and positive consequence. This component of the marketing mix is dealt 'how-to-handle-distance' (Awan, 2011).

Green Promotional Activities. Green promotion includes collaborating information on the ecological promises and the efforts made by firms to users. This component in the green marketing mix comprises numerous activities like paid advertising, direct marketing, public relations, sales promotions and on-site promotions (Fan \& Zeng, 2011). Green advertising as promotional communications is an important promotional tool that might apply to the actual demand of biologically worried buyers (Ankit \& Mayur, 2013). Green advertising communicates benefits of using green products such as less resource and energy for manufacturing products, sustainable sources, lee harmful to environment and society etc. Those massages impact on consumers' awareness and motivate to buy green products (Chang, 2011). The investigation has demonstrated that promotional activities on eco-friendly products and reference groups extensively influence consumers' buying decisions of products (Siddique \& Hossain, 2018). Green promotion includes collaborating information on the ecological promises and the efforts made by businesses to consumers (Singh, 2013). Green promotion refers to transferring real ecological information to those consumers who are participated in a firm's activities. Furthermore, firms' promise to keep natural assets is for the determination of fascinating the target audience (Shirsavar \& Fashkhamy, 2013).

Objectives of the Study. The Broad objective of the study is to investigate the green marketing mix effect on consumers' buying decisions in Bangladesh. There are some specific objectives, which are given below: to measure the level of consumers' buying decisions based on demographics; to analyse the green marketing mix effect on consumers buying decisions. Conceptual Framework and Research Hypotheses. Proposed research model, figure 1. The following hypotheses are developed from the proposed research model:

$\mathrm{H} 1$ : There is a relationship between the green product and consumers' buying decisions.

$\mathrm{H} 2$ : There is a relationship between green price and consumers' buying decisions.

$\mathrm{H} 3$ : There is a relationship between green place/distribution and consumers' buying decisions.

$\mathrm{H} 4$ : There is a relationship between green promotional activities and consumers' buying decisions. 


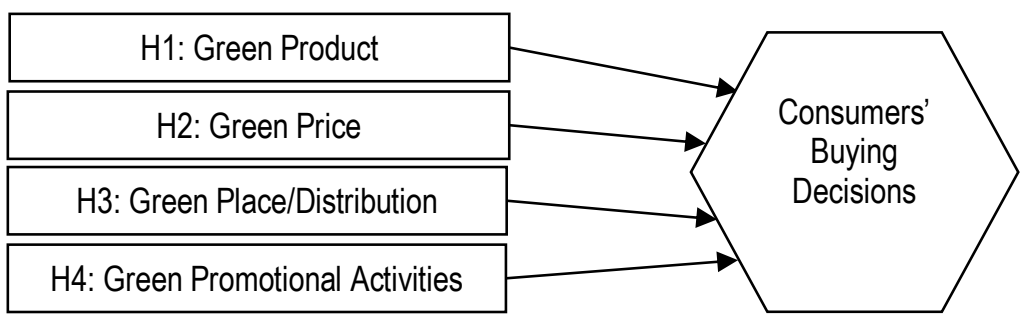

Sources: developed by the authors

Figure 1 - Proposed research model

Research Methodology. The research method which is adapted for the study is quantitative. For collecting data both primary and secondary sources are used. The primary data is gathered from the field through the administration of a structured questionnaire and personal interview. The literature review has been developed from the secondary sources. Structural questions have prepared consists of 27 items for data collections. Demographic variables are consisting of five issues including gender, age, education, occupation and monthly income. Twenty questions are regarding green marketing mix effect on consumers' buying decisions. Therefore, section 2 is composed of consumers buying decisions measures by using five point Likert scales (from $1=$ 'Strongly disagree' to $5=$ 'Strongly agree'), there is the first question with five propositions which are linked to the green product (less polluted environment, quality is high, benefit for heath, free of toxicity materials, and brand credibility), the second question with five propositions which are linked to the green price(reasonable, willing to pay, proportionate with their quality, same price, and justifies price), the third question with five propositions which are linked to the green place/distribution (store clear, more choice, product available, locality, and agents friendly to the environment), the fourth question with five propositions which are linked to the promotional activities(distinct a special day for environment, supporting the ecological centres, green advertising, green marketing campaign, and support seminar, conference and promotional programs etc.) by using five point Likert scales ( from $1=$ 'Strongly disagree' to $5=$ Strongly agree'). Fifth questions with two propositions which are linked to the consumers buying decisions (decide purchase, and satisfied consumers). Primary data is collected through a personal interview with 200 respondents by applying the convenience and judgmental sampling techniques. Cronbach's Alpha is 0.873 for 22 items of the variable which suggest that the survey instrument is reliable to measure all constructs consistently and free from random error. Data collected from the questionnaire are analysed by using frequency, mean, standard deviation and regression analysis by using SPSS 20.0.

Results and Discussions. The demographic profile of respondents. Table 1 represents the descriptive exploration on the demographic profile of respondents. Majority of the respondent is males (57.5\%) with females constituting (42.5\%). Males can be regarded as part of a growing consumers group of greening. It appeared that respondents are mostly in the age categories $20-29$ years old $(51.0 \%)$ which are called the young generation. The second highest of respondents are in the age categories 30-39 years (19.5\%). The third highest of respondents are in the age categories $40-49$ years $(16.0 \%)$. The fourth highest of respondents are in the age categories 50 years above $(7.0 \%)$, and the minority of respondents are in the age categories below 20 years (6.5\%). These young people tend to have been more concerned about the consumers buying decisions. With regards to educational qualification, $50.0 \%$ of respondents are a graduate, $16.5 \%$ of respondents are postgraduate, $10.5 \%$ of respondents are SSC passed, $21.5 \%$ of respondents are HSC passed and 1.5\% of the respondents are others. Therefore, most of the consumers are graduate. Also, with regard to employment status, greater part of respondents are service holder $(29.0 \%)$, the second highest of respondents are students $(26.0 \%)$, the third highest of the respondents are Business (19.0\%), the fourth highest of respondents are Others (13.5\%), and the minority 
of the respondents are Agriculture (12.5\%). It presented that majority of respondents are in the income level 10,000-30,000(37.5\%), the second highest of respondents are income level 30,000-50,000 (27.5\%), the third highest of respondents are income level below $10,000(14.0 \%)$, the fourth highest of respondents are in income level $50,000-80,000(13.0 \%)$, and minority of respondents are income level 80,000 above $(8.0 \%)$.

Table 1 - The demographic profile of respondents

\begin{tabular}{|c|c|c|c|c|}
\hline Variable & Frequency & Percentage & Valid \% & Cumulative $\%$ \\
\hline Gender types & & & & \\
\hline Male & 115 & 57.5 & 57.5 & 57.5 \\
\hline Female & 85 & 42.5 & 42.5 & 100.0 \\
\hline Age categories & & & & \\
\hline Below 20 & 13 & 6.5 & 6.5 & 6.5 \\
\hline $20-29$ & 102 & 51.0 & 51.0 & 57.5 \\
\hline $30-39$ & 39 & 19.5 & 19.5 & 77.0 \\
\hline $40-49$ & 32 & 16.0 & 16.0 & 93.0 \\
\hline $50+$ & 14 & 7.0 & 7.0 & 100.0 \\
\hline Education qualificati & & & & \\
\hline SSC & 21 & 10.5 & 10.5 & 10.5 \\
\hline HSC & 43 & 21.5 & 21.5 & 32.0 \\
\hline Graduate & 100 & 50.0 & 50.0 & 82.0 \\
\hline Post-graduate & 33 & 16.5 & 16.5 & 98.5 \\
\hline Others & 3 & 1.5 & 1.5 & 100.0 \\
\hline Occupation statu & & & & \\
\hline Student & 52 & 26.0 & 26.0 & 26.0 \\
\hline Business & 38 & 19.0 & 19.0 & 45.0 \\
\hline Service holder & 58 & 29.0 & 29.5 & 74.0 \\
\hline Agriculture & 25 & 12.5 & 12.5 & 86.5 \\
\hline Others & 27 & 13.5 & 13.5 & 100.0 \\
\hline Monthly income & & & & \\
\hline Below 10000 & 28 & 14.0 & 14.0 & 14.0 \\
\hline $10000-30000$ & 75 & 37.5 & 37.5 & 51.5 \\
\hline $30000-50000$ & 55 & 27.5 & 27.5 & 79.0 \\
\hline $50000-80000$ & 26 & 13.0 & 13.0 & 92.0 \\
\hline Above 80000 & 16 & 8.0 & 8.0 & 100.0 \\
\hline
\end{tabular}

Sources: developed by the authors

Descriptive statistics analysis. Green product. Table 2 reveals that out of five propositions on green product elements, one proposition means the score is 4 or above but less than 5 on likert- 5 point scale for propositions (The Product is less polluted in the environment). Therefore, most of the respondents have agreed significantly influence consumers buying decisions. For remaining four propositions (The quality of the green product is high, the product is benefited for heath, the free of toxicity materials products, and the brand of Green product is credible) mean score is 3 or above but less than 4 . Consequently, respondents have somewhat agreed to influence consumers buying decisions.

Green price. Table 2 depicts that out of five propositions on green price elements, four propositions mean score is 3 or above but less than 4 on likert- 5 point scale for propositions (The price of green product is reasonable, Consumers are willing to pay the green price, Price of the product proportionate with their quality, and Price of green and conventional products are same). As a result, most of the respondents have somewhat agreed considerably influence consumers buying decisions. For remaining one proposition (Performance of green product justifies it prices) mean score is 4 or above but less than 5 . So, respondents have agreed to influence consumers buying decisions. 
Green place/distribution. Table 2 demonstrates that out of five propositions on green place/distribution elements, all five propositions mean score is 3 or above but less than 4 on likert-5 point scale for propositions (The store in greening firms are clear, More choice of green products, The product is available in shop, The product is getting easy in locality, and The firms are keen to deal with agents friendly to the environment). Therefore, most of the respondents have somewhat agreed significantly influence consumers buying decisions.

Table 2 - Descriptive statistics analysis

\begin{tabular}{|c|c|c|}
\hline Factors & Mean & Stand. Dev. \\
\hline \multicolumn{3}{|l|}{ Green product } \\
\hline The Product is less polluted in environment & 4.1700 & .941023 \\
\hline The quality of green product is high & 3.6050 & .96104 \\
\hline The product is benefited for heath & 3.6850 & 1.03009 \\
\hline The free of toxicity materials products & 3.9900 & 1.06091 \\
\hline The brand of Green product is credible & 3.9550 & 1.07646 \\
\hline \multicolumn{3}{|l|}{ Green price } \\
\hline The price of green product is reasonable & 3.8550 & .99948 \\
\hline Consumers are willingness to pay the green price & 3.6750 & .99212 \\
\hline Price of the product proportionate with their quality & 3.7050 & 1.05525 \\
\hline Price of green and conventional products are same & 3.5500 & 1.04545 \\
\hline Performance of green product justifies its prices & 4.0150 & .92142 \\
\hline \multicolumn{3}{|l|}{ Green place/distribution } \\
\hline The store in greening firms are clear & 3.5850 & 1.13986 \\
\hline More choice of green products & 3.4950 & 1.14303 \\
\hline The product is available in the shop & 3.5850 & 1.04798 \\
\hline The product is getting easy in locality & 3.5800 & 1.11797 \\
\hline $\begin{array}{l}\text { The firms are keen to deal with agents friendly to the environment } \\
\text { Green promotional activities }\end{array}$ & 3.4950 & 1.18617 \\
\hline The firms devote a distinct a special day for the environment & 3.5000 & 1.16049 \\
\hline Firms contribute to supporting the ecological centres & 3.9450 & 1.04760 \\
\hline Green advertising is motivated to take decisions & 4.0050 & .96417 \\
\hline Green marketing campaigns are encouraged & 4.2850 & .78613 \\
\hline Firms support seminar, conference and promotional programs etc. & 3.5100 & 1.21956 \\
\hline
\end{tabular}

Sources: developed by the authors

Green promotional activities. Table 2 demonstrates that out of five propositions on green promotional activities, three propositions mean score is 3 or above but less than 4 on likert- 5 point scale for propositions (The firms devotes a distinct a special day for the environment, Firms contribute in supporting the ecological centres, and Firms support seminar, conference and promotional programs etc.). Therefore, most of the respondents have somewhat agreed significantly influence consumers buying decisions. For remaining two propositions (Green advertising is motivated to take decisions, and Green marketing campaigns are encouraged) mean score is 4 or above but less than 5 . Consequently, respondents have agreed to influence consumers buying decisions. The result of Regression Analysis, table 3.

Table 3 - Predict the relationship between green marketing mix and buying decisions

\begin{tabular}{|c|c|c|c|c|}
\hline \multicolumn{5}{|c|}{ Model Summary } \\
\hline Model & $\mathbf{R}$ & R Square & Adjusted R Square & Std. The error of the Estimate \\
\hline 1 & .546 & .298 & .280 & .91326 \\
\hline
\end{tabular}

Sources: developed by the authors

Predict the relationship between green marketing mix and buying decisions. Table 3 presents that the 
value of the correlation coefficient, $R=0.546$ suggests that there is a moderate positive correlation between consumers buying decisions and green marketing mix. However, only $29.8 \%$ (R-square values of 0.298 ) variation in consumers buying decisions accounted for due to the green marketing mix.

Table 4 - Confirm the model fitness (Analysis of variance)

\begin{tabular}{|c|c|c|c|c|c|c|}
\hline \multicolumn{9}{|c|}{ ANOVA } \\
\hline \multirow{2}{*}{1} & Model & Sum of Squares & Df & Mean Square & F & Sig. \\
\cline { 2 - 7 } & Regression & 68.791 & 4 & 13.758 & 16.496 & .000 \\
\cline { 2 - 7 } & Residual & 161.804 & 195 & .834 & & \\
\cline { 2 - 7 } & Total & 230.595 & 199 & & & \\
\hline
\end{tabular}

Sources: developed by the authors

Confirm the model fitness (Analysis of variance). Table 4 reveals that multiple regression analysis is performed to investigate the relationship between green marketing mixes with consumers buying decisions. Four factors are proposed, and results are enumerated in table 4 . F-statistics produced ( $f=$ 16.496) is significant at 1 per cent level (sig. $f<0.01$ ) with 4 and 195 degrees of freedom, thus confirming the fitness for the model. The adjusted $\mathrm{r} 2$ is 0.280 (From table 3 ), connoting that the four factors can significantly account for $28 \%$ variance in the consumers buying decisions.

Table 5 - Effect of the green marketing mix on consumers buying decisions

\begin{tabular}{|c|c|c|c|c|c|c|}
\hline & \multicolumn{6}{|c|}{ Coefficients } \\
\hline & \multirow{2}{*}{ Model } & \multicolumn{2}{|c|}{ Unstandardized Coefficients } & \multirow{2}{*}{$\begin{array}{c}\text { Standardized } \\
\text { Coefficients } \\
\text { Beta }\end{array}$} & \multirow[t]{2}{*}{$T$} & \multirow{2}{*}{ Sig. } \\
\hline & & B & Std. Error & & & \\
\hline \multirow{5}{*}{1} & (Constant) & -.141 & .473 & & -.299 & .765 \\
\hline & Green product & 441 & .112 & .265 & 3.950 & .000 \\
\hline & Green price & .068 & .102 & .049 & .670 & .504 \\
\hline & Green place/ distribution & 128 & .095 & .096 & 1.344 & .181 \\
\hline & Green promotional activities & 329 & .092 & .255 & 3.587 & .000 \\
\hline
\end{tabular}

Sources: developed by the authors

Effect of the green marketing mix on consumers buying decisions. The results of multiple regression analysis in table 5 that green product as the important elements, which significantly influence consumers' buying decisions ( $\beta 1=0.265 ; \mathrm{t}$-value $=3.950 ; p<0.05$ ). $\mathrm{H} 1$ is accepted. Therefore, green product elements are influenced consumer's buying decisions. Next, green promotional activities as the vital elements, which notably influence consumers buying decisions ( $\beta 4=0.255$; t-value $=3.587 ; p<0.05$ ). $\mathrm{H} 4$ is accepted. Consequently, green promotional activities elements are influenced consumer's buying decisions. The results in Table 5 denotes that green price elements insignificantly influence consumers buying decisions $(\beta 2=0.049 ; \mathrm{t}$-value $=.670 ; p>0.05)$. $\mathrm{H} 2$ is not accepted. Therefore, green price elements have no effect on consumers buying decisions. Next, green place/distribution elements insignificantly influence consumers buying decisions $(\beta 3=0.096$; $t$-value $=1.344 ; p>0.05$ ). $\mathrm{H} 3$ is not accepted. Thus, green place/distribution elements have no effect on consumers buying decisions.

Conclusion and Implications. The paper has been undertaken with an objective to explore the green marketing mix effect on consumers' buying decisions in Bangladesh. The investigation examines the green product, green price, green place/distribution, and green promotional activities elements that influence consumers' buying decisions. From the results of regression analysis, this research is revealed that green product and green promotional activities as the important elements, which influence consumers buying decisions. On the other hand, from regression analysis, green price and green place/distribution elements 
don't influence consumers buying decisions. The study has implications for marketers as well as green consumers and makes a good case for introduce of an era of greening in Bangladesh. The study shows that consumers' buying decisions really seem influenced by marketing mix's green product and green promotional activities. So, marketers should maintain promotional campaigns for increasing the knowledge regarding greening. Marketers also have to develop more displays, samples, commercialization and distribution in order to green information available. The findings of this exploration may be helpful for both inspector and green companies. For researchers, this exploration gives instruction for accepting to buy, demographics level, and their relative importance. Literature for future examination, this research designates ways to identify additional thoughtful green marketing mix elements which impact on consumers buying decisions. Besides, this investigation provides the realistic path and appropriate suggestions to the greening firms. Greening firms will be profited identifying marketing mix elements of consumers buying decisions. Those categories of the greening practising firms will offer to Bangladeshi consumers for buying decisions.

Limitation and Further Research. The study is restricted in inside Bangladesh only and the result may not be applicable to other places. This data may not be the true representative of Bangladeshi consumers. The result is obtained based on the respondents' opinion. So, there is a chance of a respondent's bias. The respondents don't want to disclose their personal information. The sample size is only 200 . Future research is recommended to improve the significance of the sampling by expanding the sample size and carrying out the survey in different geographical areas. Next, a study on the moderating effect of demographics with consumers buying decisions is deemed relevant by using multivariate data analysis technique. The study conducted in green marketing mix only as the independent variable. Therefore, there may be some other variables which may influence consumers buying decisions. Those elements are left for the upcoming study.

\section{References}

Ankit and Mayur (2013). Green Marketing: Impact of Green Advertising on Consumer Purchase Intention. Advances Manage, 6(9), $14-17$.

Awan (2011). Green marketing: Marketing strategies for the Swedish energy companies. International Journal of Industrial Marketing, 1(2), 1-19,

Bukhari (2011). Green Marketing and Its Impact on Consumer Buying Behavior. Eur. J. Econ. Political Stud., 3(4), 375-383.

Chang, C. (2011). Feeling Ambivalent about Going Green - Implication for Green Advertising Processing. Journal of Advertising, 40(4), 19-319. https://doi.org/10.2753/JOA0091-3367400402.

Cherian, J., and Jacob, J. (2012). Green Marketing: A Study of Consumers 'Attitude towards Environment-Friendly Products. Asian Social Science, 8(12), 117-126.

Dahl, U., and Persson, S. (2008). Purchasing of environmental friendly computers, Bachelor Thesis within Business Administration, Jonkoping International Business School.

D'Souza et al. (2006). Green Products and Corporate Strategy: An Empirical Investigation. Society and Business Review, 1(2), 144-157

Durning, A.T. (2011). How much is enough? Earthsvan, London

Eric K (2007). Green marketing practices by Kenya petroleum refineries: A study of the perception of the management of oil marketing companies in Kenya. Ph.D. Dissertation, University Of Nairobi, Kenya.

Fan and Zeng (2011). Implementation of green marketing strategy in China: A study of the green food industry. M.Sc. Thesis, University of GAVLE, China.

Gan, C., Wee, H. Y., Ozanne, L., and Kao, T. (2008). Consumers Purchasing Behavior toward Green Products in New Zealand. Innovative Marketing. 4(1), 93-102.

Hashem, Tareq N. and Al-Rifai, Nahla A. (2011). The Influence of applying Green Marketing Mix by Chemical Industries Companies in Three Arab States in West Asia on Consumer's Mental Image. International Journal of Business and Social Science, 2(3), 92-101.

Kalama (2007). Green Marketing Practices by Kenya Petroleum Refineries: A Study of the Perception of the Management of Oil Marketing Companies in Kenya. Doctoral dissertation, School Bus., Univ. Nairobi, Kenya.

Kassaye, W. W., and Verma, D. (1992). Balancing traditional packaging functions with the new 'green. S.A.M. Advanced Management Journal, 57(4), 15. 
Kollmuss, A. and Agyeman, J., (2002). Mind the gap: why do people act environmentally and what are the barriers to proenvironmental behaviour?. Environmental Education Research, 8(3), pp. 239-260.

Kotler, P., and Armstrong, G. (2009). Principles of Marketing. Prentice Hall, New Jersey.

Kotler, P., and Armstrong G. (1999). Principles of marketing Prentice-Hall International Inc.

Kumar and Ghodeswar (2015). Factors affecting consumers' green product purchase decisions. Marketing Intelligence and Planning, 33(3), 330-347.

Mahmoud, T.O., (2018). Impact of green marketing mix on purchase intention. International Journal of Advanced and Applied Sciences, 5(2), 127-135.

Martin, D., and Schouten, J. (2012). Sustainable marketing. Upper Saddle River, N.J.: Pearson Prentice Hall.

Ottman, J. (1992). Sometimes consumers will pay more to go green. Marketing News (July 6), 16.

Panni, M.F.A.K., (2006). The Effect of Consumerism towards customer attitudinal behavior in food industry in Malaysia. M.Phil. Multimedia University.

Peattie, K. (1995). Environmental marketing management, London: Pitman Publishing.

Prakash, A. (2002). Green Marketing, Public Policy and Managerial Strategies. Business Strategy \& the Environment, 11(5), 285-297. https://doi.org/10.1002/bse.338.

Pride, W. M. and O.C. Ferrel, (2008). "Marketing", 14th edition. New York: Houghton Mifflin.

Shamdasani, P., Chon-Lin, G. and Richmond, D. (1993). Exploring green consumers in an oriental culture: Role of personal and marketing mix. Advances in consumer research, 20, 488-493.

Shil (2012). Evolution and Future of Environmental Marketing. Asia Pacific J. Marketing Manage. Rev., 1(3), 74-81.

Shirsavar and Fashkhamy (2013). Green marketing: A new paradigm to gain competitive advantage in contemporary business. Trends in Advanced Science and Engineering, 7(1), 12-18.

Siddique, Z. R. and Hossain, A., (2018). Sources of Consumers Awareness toward Green Products and Its Impact on Purchasing Decision in Bangladesh. Journal of Sustainable Development, 11(3), 9-22.

Singh (2013). Green: The New Colour of Marketing in India. ASCl J. Manage., 42(2), 52-72.

Sivesan, S., Achchuthan, S. and Umanakenan, K., (2013). Green Marketing Practices and Customer Satisfaction: A Special Reference to Leather Goods. Global Journal of Management and Business Research Accounting and Auditing, 13(3), 50-59.

Soonthonsmai, V. (2007). Environmental or green marketing as global competitive edge: Concept, synthesis, and implication. EABR (Business) and ETLC (Teaching) Conference Proceeding, Venice, Italy.

Wasik, J.F. (1996). Green marketing and management: A global perspective. Cambridge, Mass: Blackwell Publishers Inc.

Welford, R. (2000). Hijacking environmentalism. London: Earthscan.

Yazdanifard and Mercy (2011). The Impact of Green Marketing on Customer Satisfaction and Environmental Safety. International Conference on Computer Communication and Management, Proc. Of CSIT vol. 5, IACSIT press, Singapore. pp. 637-641.

A. Хосеін, Університет Комілла (Бангладеш);

Mд. Ю.Х.ХХн, Університет Алгарве (Португалія); Міжнародний університет аграрного бізнесу та технологій (Бангладеш).

Вплив зеленого маркетингу на поведінку споживачів в Бангладеші

Термін «зелений» - широко використовуваний та набуває конкретного змісту в залежності від специфіки досліджуваної ситуації. Так, у статті автори визначають, що зелений маркетинг - це сучасна філософія, яка може бути перенесена на товари кінцевого споживання, виробництво товарів та послуг. У роботі розглядається зелений маркетинг як маркетинг продуктів, які сертифіковані як екологічно безпечні. Зелений маркетинг об'єднує низку заходів та програм, включаючи. адаптацію продукції, зміну способу виробництва, зміну упаковки, зміну цін, а також зміну рекламної ідеї. У рамках даного дослідження, автори оцінюють вплив зеленого маркетингу на процес прийняття рішень споживачами у Бангладеші, використовуючи методи кількісного аналізу. Детерміновану вибірку даних було сформовано на основі результатів опитування 200 респондентів. 3 метою оцінки отриманих даних було розраховано частоту, середнє квадратичне відхилення та проведено регресійний аналіз. Емпіричні результати регресійного аналізу підтвердили гіпотезу, що зелена продукція та зелена рекламна діяльність $\epsilon$ важливими факторами впливу на процес прийняття рішення споживачами. Автори наголошують, що отримані результати підтверджують необхідність переходу до концепції зеленого зростання Бангладешу. Отримані результати підтверджують, що зелена продукція та зелена рекламна діяльність позитивно впливають на поведінку споживачів. Таким чином, маркетологи повинні підтримувати рекламні кампанії з урахуванням основних принципів зеленого маркетингу. При цьому, автори наголошують на необхідності проведення рекламних акцій з урахуванням принципів зеленого маркетингу з метою поширення ідеології зеленого зростання серед суспільства. У роботі авторами запропоновано механізм озеленення як маркетингової діяльності, так і компанії в цілому. Так, компанії зможуть пропонувати споживачам зелену продукцію, що тим самим призведе до зростання популярності зеленої продукції серед споживачів Бангладешу.

Ключові слова: Бангладеш, рішення, споживач, зелений маркетинг.

Manuscript received: 02.10.2018

(C) The author(s) 2018. This article is published with open access at Sumy State University. 